\title{
МОНТТОРИНГ ЗНАНЬ СТУДЕНТІВ ПЕРШИХ КУРСІВ ЧОРТКІВСЬКОГО ДЕРЖАВНОГО МЕДИЧНОГО КОЛЕДЖУ ЩОДО ПРОБЛЕМ ЙОДОДЕФІЦИТУ
}

\author{
Л. В. Сенюк, Н. В. Пасєчко \\ Чортківський державний медичний коледж \\ ДВНз «Тернопільський державний медичний університет \\ імені І. Я. Горбачевського МОЗ Украӥни"
}

У статті висвітлено питання обізнаності студентів стосовно проблем йододефіциту.

\section{MONITORING OF FIRST YEAR STUDENTS ` KNOWLEDGE OF CHORTKIV STATE MEDICAL COLLEGE ACCORDING IODINE DEFICIENCY PROBLEMS}

\author{
L. V. Senyuk, N. V. Pasyechko \\ Chortkiv State Medical College \\ I. Horbachevsky Ternopil State Medical University
}

The article highlights the awareness of students about the problems of iodine deficiency.

Вступ. Людський організм - як злагоджений оркестр. Коли всі органи і системи діють злагоджено, - здоров'я «звучить» гармонією. Звісно, кожен із «інструментів» $є$ важливим і незамінним, але $є$ серед них такі, дисфункція яких повністю «знеструмлює» організм. Скажімо, щитоподібна залоза, від роботи якої залежить буквально все: нервова, серцевосудинна система, мозкова і психічна діяльність, репродуктивна й ендокринологічна функції [1].

Рівень ендокринологічної захворюваності як один із показників стану здоров'я населення має тенденцію до зростання. Ендокринна патологія сьогодні займає третє місце серед захворювань органів та систем. Серед ендокринної патології перше місце посідає захворювання щитоподібної залози, випереджаючи цукровий діабет [2].

Основна функція щитоподібної залози - синтез і виділення в кров специфічних гормонів: тироксину, трийодотироніну і кальцитоніну. Тироксин і трийодотиронін, які в сукупності називаються тиреоглобуліном, є йодовмісними амінокислотами, синтезуються фолікулами. У їх склад входить йод. Фолікулярні клітини залози мають унікальну властивість захоплювати 3 крові йод. У нормі залоза поглинає близько 50 \% йоду, що надходить в організм, який швидко викорис-

(с) Л. В. Сенюк, Н. В. Пасєчко, 2016 товується для синтезу тиреоїдних гормонів. Оскільки тиреоїдні гормони мають у своєму складі йод, для забезпечення їх синтезу потрібне його надходження в організм [3].

Йод належить до життєво важливих мікроелементів: добова потреба в ньому залежить від віку і складає від 100 до 200 мкг. За все життя людина споживає близько 5 г йоду, що еквівалентно вмісту однієї чайної ложки [4].

До організму йод потрапляє як органічний, так і неорганічний, з їжею та рідиною, лікарськими препаратами. Він у вигляді йодидів всмоктується в кишечнику. Течією крові розноситься по організму і концентрується переважно в щитоподібній залозі зі швидкістю 2 мкг/год [3].

Йод - це життєво важливий мікроелемент. Він має заспокійливу дію на організм і нервову систему. При нервовому напруженні, дратівливості, безсонні $є$ потреба в йоді для розслаблення організму і оптимістичного настрою. Йод - один з кращих каталізаторів окиснення. При його недостачі відбувається неповне згорання їжі, що призводить до небажаного утворення жирових запасів. Йод відновлює енергію людини. Він необхідний для формування і нормального функціонування щитоподібної залози. Використовується для синтезу гормону - тироксину, який, в свою чергу, впливає на обмінні процеси практично всіх органів 
та систем організму [5]. При нестачі даного мікроелемента в організмі розвиваються йододефіцитні захворювання.

Йододефіцитними захворюваннями (ЙДЗ), за визначенням ВООз, є всі патологічні стани, що розвиваються в популяції у результаті дефіциту йоду, яким можна запобігти при нормалізації його споживання [6].

На жаль, на значній частині території України спостерігається природний йододефіцит - це регіони ендемічної патології щитоподібної залози, зокрема територія Західної України. Західний регіон України, що представлений різними кліматогеографічними зонами (гори, передгір'я, рівнини) вважається найбільшим ендемічним регіоном щодо зоба, з розповсюдженою патологією серед усіх верств населення. Західні області України є частиною двох ендемічних щодо зоба смуг місцевості: Карпатської і БілоруськоВолинської. Дуже важливо зрозуміти, що йододефіцит це не захворювання, це передумова захворювання. Багато людей вважають, що проблема йододефіциту їх не стосується. Насправді - це стосується кожного.

Дефіцит йоду - надзвичайно актуальна проблема. Тернопільська область $є$ регіоном йодної недостатності середньої тяжкості, що спричиняє високий рівень йододефіцитних захворювань, в тому числі й зоба [7]. У нас головним джерелом надходження йоду в організм є йодована сіль та морські продукти, в яких $\epsilon$ цей життєво необхідний мікроелемент.

Дефіцит йоду, через його вплив на розвиток мозку, погіршує якість життя мільйонів людей, та є причиною відставання у фізичному та психічному розвитку. У світовому масштабі дефіцит йоду є єдиною причиною ураження головного мозку, якої можна запобігти [8].

Мета дослідження - розглянути поняття йододефіциту, умови виникнення та наслідки. Вивчити проблему йододефіциту серед студентів перших курсів і сприяти підвищенню рівня знань з даного питання. Розширити знання студентів про функції йоду в організмі людини.

Основна частина. Об'єктом дослідження стали студенти першого курсу Чортківського державного медичного коледжу. Дослідження проводилось методом опитування (анкетування), аналізу та статистичної обробки даних.

До уваги студентів була запропонована анкета, яка містила такі запитання: «Чи $є$ у вашій дієті 2 рази на тиждень морепродукти?», «Чи користуєтесь ви йодованою сіллю?», «Чи були у вас проблеми із щитоподібною залозою?», «Чи приймали ви препарати йоду?»
При обробці результатів були проаналізовані анкети 454 студентів новонабраних груп. Серед опитуваних було 103 хлопці (23\%) та 351 дівчина (77\%) віком від 14 до 22 років, середній вік опитуваних 18 років.

Опрацювавши анкети студентів було виявлено, що 151 студент (33 \%) 2 рази на тиждень має у своєму раціоні харчування морепродукти. Що стосується йодованої солі, то практично всі респонденти чули про неї і тільки 198 студентів (44 \%) використовують їі у своєму раціоні харчування. У 95 студентів (21\%) були проблеми із щитоподібною залозою. 117 студентів (26 \%) приймали препарати йоду.

Отримані дані наштовхують на думку, що студенти $\epsilon$ малообізнані у питаннях йододефіцитних захворювань та про наслідки даної проблеми. Можливо, навіть і не підозрюють, що це важлива тема, яка потребує особливої уваги. Адже, йододефіцит може вивести із ладу практично всі органи і системи організму людини.

Значення йоду для нормального функціонування людського організму важко переоцінити. Йодний дефіцит, що виникає в дитинстві або в підлітковому віці, призводить до формування зоба, затримки фізичного і розумового розвитку. Такі діти відстають від ровесників у рості, погано навчаються, в них сповільнюється статеве дозрівання. Особливо високий ризик виникнення йодного дефіциту в підлітків, коли потреба в тиреоїдних гормонах підвищується через більш швидке їх використання в процесі активного росту і більш швидкого використання йоду, що поступає в організм [9].

Дефіцит йоду $\epsilon$ небезпечним, особливо для молодих дівчат. Це пов'язано з тим, що нестача йоду вкрай негативно позначається на здоров'ї жінки в подальшому. Зокрема, небезпека полягає в можливому розвитку патологій головного мозку в майбутніх дітей цих дівчат [10].

Тому потрібно активно пропагувати споживання в раціоні морепродуктів та йодованої солі, особливо студентам. Нормальне функціонування щитоподібної залози дозволяє організму гармонійно розвиватися, забезпечує правильний обмін речовин, нормальний рівень гемоглобіну в крові, ефективну роботу серцевосудинної системи, опорно-рухового апарату, активність, підвищений імунітет і інтелектуальний потенціал.

Дефіцит йоду - це так званий «керований дефіцит», котрий може бути ліквідований внесенням необхідної речовини у вигляді препаратів та продуктів харчування, у тому числі збагачених (функціональних) [11]. 
Висновки. Поширеність захворюваності щитоподібної залози та інші проблеми зі станом здоров'я, внаслідок йодного дефіциту, спонукають до прийняття невідкладних заходів. Особливо велику небезпеку викликає дефіцит йоду в організмі молодих людей. Зокрема, зі зниженням рівня забезпечення йоду в організмі, спостерігається зниження психомоторної енергійності, комунікативної та інтелектуальної активності і, відповідно, коефіцієнта інтелекту (IQ). Також знижується коефіцієнт когнітивної ригідності, який свідчить про пластичність і гнучкість мислення та здатність легко переходити від одного виду діяльності до іншого.

\section{ЛІТЕРАТУРА}

1. Гульчій М. В. Щит для «щитовидки» / М.В.Гульчій // Україна молода. - 2015. - 05 березня. - № 32.

2. Караченцев Ю. І. Особливості перебігу та тактика лікування тиреоїдної патології в Україні на сучасному етапі / Ю. І. Караченцев // Вісник наукових досліджень. 2001. - C. 5.

3. Залози внутрішньої секреції та обмін речовин: опорний конспект лекцій / уклад. Швайко С. Є. [та ін.]. Луцьк, 2009. - 424 с.

4. Шідловський В. О. Йододефіцитні захворювання: діагностика, лікування, профілактика / В. О. Шідловський, І. М. Дейкало, О. В. Шідловський. - Тернопіль : ТДМУ, 2006. - 82 c.

5. Власюк П. А. Микроэлементы в жизни растений, животных и человека / П. А. Власюк. - К. : Знання, 1986. -39 c.
Проведене дослідження показало необхідність відновлення періодичного проведення бесід з питань профілактики йододефіцитних захворювань. Інформація буде спрямована на заохочення до регулярного споживання йодовмісних продуктів харчування. Насичення ними раціону дозволить значною мірою вирішити питання про забезпечення організму достатньою кількістю йоду.

У подальшому потрібно працювати над питаннями пропаганди раціонального харчування та споживання достатньої кількості продуктів, збагачених йодом.

6. Шідловський В. О. Йодний дефіцит і йододефіцитні захворювання : посібник для лікарів / В. О. Шідловський, І. М. Дейкало, О. В. Шідловський. - К. : 2004. - 69с.

7. Шідловський В.О. Хірургія зоба в ендемічному регіоні / В. О. Шідловський, І. М. Дейкало, О.В.Шідловський // Шпитальна хірургія. - 2012. - № 2. - С. 24.

8. Оцінювання йододефіцитних захворювань та моніторинг їх усунення : посібник для керівників програм. 3 вид. - К. : «К.І.С.», 2008. - 104 с.

9. Благосклонная Я. В. Заболевания щитовидной железы: современное лечение и профилактика / Я. В. Благосклонная, А. Ю. Бабенко, Е. И. Красильникова. - СПб. : ИК «Невский проспект», 2005. - 128 с.

10. Кравченко А. Панацея XXI века. Йод спасает жизни I А. Кравченко. - К. : ЛОТОС, 2011. - 64 с.

11. Роль мікроелементів у етіології йододефіцитних захворювань / В.Н.Корзун, Ю. С. Котикович, І. Ю. Антонюк, [та ін.]. // Проблеми харчування. - 2011. № 3-4. - С. 29. 